\title{
CONTRACTUAL REVISIONS TO MEDICAL MALPRACTICE LIABILITY
}

\author{
William H. GinsburG* \\ Steven J. KaHN $†$ \\ Michael C. Thornhill** \\ and Steven C. Gambardella $†$ †
}

I

Introduction: Changing Economic Realities Should Make Contractual Limitations More Enforceable

\section{A. The Traditional View}

In the past, courts have struck down or severely limited attempts by health care providers to use written contracts to reduce their liability for negligence, deeming such agreements to be contrary to public policy.' The basic reason is that courts have not traditionally viewed the relationship of patient and health care provider as a contractual one, freely entered by both parties. Rather, physicians and hospitals have been classified, like innkeepers, utilities, and common carriers, as entities to which individuals, with no real bargaining power, must resort out of necessity. Hence, courts have not really analyzed exculpatory patient/health care provider agreements in terms of mutuality of bargaining or "arm's-length" negotiation. Instead, courts have simply rejected them out of hand as contrary to the public interest. The decisions cite one or more of the following overlapping rationales:

(a) Medical care is a necessity of life over which the superior bargaining power of the provider should not prevail ${ }^{2}$

(b) Exculpatory clauses have no place in the practice of the learned profession; ${ }^{3}$

Copyright $@ 1986$ by Law and Contemporary Problems
* Senior Partner, Wood, Lucksinger \& Epstein.
$+\quad$ Associate, Wood, Lucksinger \& Epstein.
* Associate, Wood, Lucksinger \& Epstein.
$+\dagger$ Associate, Wood, Lucksinger \& Epstein.
1. Annot., 6 A.L.R.3D 704-07 (1966) (citing Tunkl v. Regents of the Univ. of Cal., 60 Cal. 2d 92, 383 P.2d 441, 32 Cal. Rptr. 33 (1963), and three earlier cases).

2. "That the services of the hospital to those members of the public who are in special need of the particular skill of its staff and facility constitute a practical and crucial necessity is hardly open to question." Tunkl v. Regents of the Univ. of Cal., 60 Cal. 2d 92, 101, 383 Pac.2d 441, 447, 32 Cal. Rptr. 33, 39 (1963).

3. Olson v. Molzen, 558 S.W.2d 429, 430 (Tenn. 1979) (citing W. Jaeger, Williston on Contracts $\$ 1751$ (3d ed. 1972), which states that "[some] relationships are such that once entered upon they involve a status requiring of one party greater responsibility than that required of the ordinary person, and, therefore, a provision avoiding liability is peculiarly obnoxious") (invalidating abortion clinic's exculpation clause). 
(c) Private agreements should not reduce a health care provider's statutory or ethical duties; ${ }^{4}$

(d) Health care providers have a nonnegotiable duty of public service; ${ }^{5}$

(e) Health care providers should not be able to violate prevailing standards of care with impunity; 6

(f) Patients cannot be expected to choose among health care providers based on contractual terms affecting the provider's liability for negligence; ${ }^{7}$

(g) There is no assurance that other available and comparable health care providers will not impose similar limitations; ${ }^{8}$

(h) The disparity of bargaining power between provider and patient is too extreme to give any normative weight to the results of bargaining; 9

(i) The financial risk of personal injury should be borne by a negligent party when that party is in a much superior economic position and capable of taking measures to prevent or insure against losses. ${ }^{10}$

From today's perspective, two things are notable about such traditional legal policy assertions. First, courts were predisposed to reject contractual redefinition of liability rules because most such attempts were one-sided efforts by the health care provider to completely exculpate itself from tort liability. ${ }^{11}$ The contracts provided no alternative means of assessing liability, imposed no burden on the provider in the event of negligence, and offered no other assurance to the patient against the adverse consequences of the provider's negligence. There were no attempts to substitute contractually developed standards of care or processes to achieve fair, impartial adjudication of rights and grievances. Where courts have considered a less one-sided contractual alternative-an agreement by the patient to arbitrate all claims against the health care provider-courts have been far more receptive. ${ }^{12}$

Second, the various rationales upon which courts have invalidated health care providers' exculpatory clauses have rested on abstract "public policy"

4. Porubiansky v. Emory Univ, 156 Ga. App. 602, 275 S.E.2d 163, (1980), affd, 248 Ga. 391 , 282 S.E.2d 903 (1981) (physician's ethical duty not to render substandard care); Leidy v. Deseret Enters., 252 Pa. Super. 162, 381 A.2d 164 (1977) (licensing law established a duty not to render physical therapy contrary to a physician's instructions).

5. Smith v. Hospital Auth,, 160 Ga. App. 387, 389-90, 287 S.E.2d 99, 100 (1981) (blood extraction); Meiman v. Rehabilitation Center, 444 S.W.2d 78, 80 (Ky. App. 1969) (rehabilitation center); Schlobohm v. Spa Petite, 326 N.W.2d 920, 924 (Minn. 1982).

6. Emory University v. Porubiansky, 248 Ga. 391, 394, 282 S.E.2d 903, 905 (1981).

7. Wheeler v. St. Joseph Hosp., 63 Cal. App. 3d 345, 358-60, 133 Cal. Rptr. 775, 784-86 (1976); Olson v. Molzen, 558 S.W.2d 429, 431 (Tenn. 1979). See generally Henderson, Contractual Problems in the Enforcement of Agreements to Arbitrate Medical Malpractice, 58 VA. L. REv. 947, 987 (1972) (discussion of patients' expectations when entering into contracts with providers).

8. Belshaw v. Feinstein, 258 Cal. App. 2d 711, 725-27, 65 Cal. Rptr. 788, 798 (1968) (defendants were only area physicians who performed stereotaxic surgery); Olson v. Molzen, 558 S.W.2d 429, 431 (Tenn. 1979).

9. Tunkl v. Regents of the Univ. of Cal., 60 Cal. 2d 92, 101, 383 P.2d 441, 447, 32 Cal. Rptr. 33, 39 (1963). But cf. Robinson, Rethinking the Allocation of Medical Malpractice Risks Between Patients and Providers, Law \& Contemp. Probs., Spring 1986, at 173, 185-88.

10. Tunkl v. Regents of the Univ. of Cal., 60 Cal. 2d 92, 100-01, 383 P.2d 441, 446-47, 32 Cal. Rptr. 33, 38-39 (1963).

11. See cases cited supra notes 2-10. The only case where total exculpation was not attempted is Tatham v. Hoke, 469 F. Supp. 914 (W.D.N.C. 1979), where an abortion clinic's admission agreement limited damages to $\$ 15,000$.

12. See generally Annot., 84 A.L.R.3D 375 (1978). 
considerations gleaned from statutory and common law rules, rather than on actual consideration of the particular provider/patient relationship involved in the specific proposed alteration. Courts have accepted without question a traditional view of powerless patients and all-powerful providers.

\section{B. Changing Circumstances}

Public policy, fortunately, is an adaptive and dynamic concept. Recently, health care financing and delivery have become more concerned with containment of medical spending and purchaser control over health care. This reality should lead to a different view by legislatures and courts and allow enforcement of reasonable contractual revisions to medical malpractice liability and tort recoveries. What limits might be deemed reasonable? 13 Well-measured limitations which address traditional public safety concerns would simultaneously promote this valuable public policy, and provide more affordable health care and freedom of choice by consumers.

Legitimate judicial concern about unequal bargaining power and overreaching in health care can be alleviated by showing that consumers are indeed protected. Courts can judge the validity of alternative liability provisions in private contracts for health care delivery by weighing two crucial aspects of the bargain: (1) the degree to which the consumer has freedom of choice, measured by such factors as the parties' relative size and the availability of alternatives; and (2) the degree to which the terms are objectively conscionable, measured by the extent to which the contract allows redress for the injured party.

Courts should be persuaded to adjudicate the enforceability of private modifications of previously determined rights according to where they fit in this context. A relatively conscionable term, such as abrogation of the collateral source rule, should be enforceable unless the patient was denied all freedom of choice. A complete exculpation, on the other hand, should be enforceable only if the consumer had a very high degree of freedom of choice.

An example of such a high degree of freedom of choice is an agreement for health care between a large employer, such as General Motors or the State of California, and a health maintenance organization (HMO), that includes contract limits on malpractice liability. In such circumstances, other insurance or prepaid health plans are typically offered to the employee, each of which might feature different bargained-for malpractice limitations (or none) ${ }^{14}$ Clearly, patient interests are represented here: the consumer is not a patient coerced by pain and utterly dependent on the judgment of the other party. Rather, it is an entity with economic power to accept or reject the contracts offered by HMO's and other alternative delivery systems based, inter alia, on their rates and the extent to which they limit malpractice liability.

13. See Havighurst, Altering the Applicable Standard of Care, Law \& Contemp. Probs., Spring 1986, at $265,266$.

14. Herzlinger \& Schwartz, How Companies Tackle Health Care Costs: Part I, Harv. Bus. Rev., JulyAug. 1985, at 68 . 
Furthermore, the individual has the final choice of which option to accept personally. At the other extreme of this continuum is the patient transported to an emergency room by ambulance or paramedics, for whom it can truly be said there is "no bargaining table." 15

Major changes now occurring in the delivery of health care in this country will increase the instances in which there will be a true bargaining table. The growth of HMO's, preferred provider organizations (PPO's), and other alternative delivery systems will result in more consumers bargaining in advance for the type of care they desire. ${ }^{16}$ Although HMO's are now still held to the same malpractice standard of care as other providers, their enrollees are clearly opting for a different type of health care delivery than that traditionally made available. ${ }^{17}$ Just as importantly, enrollees may make their choice in advance of their need for such services. Unlike most of the plaintiffs noted above who signed exculpatory contracts, today's HMO enrollees are not in the throes of sickness or injury when they arrange for the delivery of health care services. They are making informed decisions in advance, and are strongly motivated by economic factors. ${ }^{18}$

The availability of alternatives in health care is another major factor determining whether the consumer has sufficient bargaining power to make agreements that are nonadhesive and, hence, enforceable. ${ }^{19}$ Where the employer or a union presents the employee-consumer with a "menu" of prepaid health plans and other insurance benefits, choice is clearly guaranteed. In addition to being offered a choice among competing plans, any one prepaid health plan or health care provider might offer the consumer a variety of alternative arrangements, such as varying limitations on malpractice liability, or no limitations on liability. The alternatives that do not limit the plan or provider's traditional liability might feature higher premiums or fees. Alternatively, to obtain unlimited negligence liability and remedies, the consumer might have the option of paying a surcharge, a lump sum payment reasonably equivalent to the provider's increased costs for assuming the risks of injury to the patient. Another option might be to purchase "spot" insurance-insurance which would cover the patient in the event of certain injuries or losses, whether occasioned by negligence or not. Those who want extra protection thus would have a practical alternative, but would also have to pay extra.

Another factor in determining the degree of freedom of choice is the extent to which the offered limitations and the available alternatives are

15. Tunkl v. Regents of the Univ. of Cal., 60 Cal. 2d 92, 102, 383 P.2d 441, 447, 32 Cal. Rptr. 33, 39 (1963).

16. Madden v. Kaiser Found. Hosps., 17 Cal. 3d 699, 710-11, 552 P.2d 1178, 1185, 131 Cal. Rptr. 882, 889 (1976); Fine \& Sunshine, Malpractice Reform Through Consumer Acceptance and Consumer Education: Are the New Concepts Marketable?, Law \& ConTemp. Probs., Spring 1986, at 213, 218.

17. H. Luft, Health Maintenance Organizations: Dimensions of Performance 40-57 (1981).

18. Schuttinga, Falik \& Steinwald, Health Plan Selection in the Federal Employees Health Benefit Program, 10 J. Health Pol., Pol'y \& L. 119, 132-37 (1985).

19. Olson v. Molzen, 558 S.W.2d 429, 431 (Tenn. 1979). 
disclosed to the patient or enrollees. A limitation provision buried in the fine print of a contract would probably be unenforceable. ${ }^{20}$ In other consumer contexts, legislation requires explicit wording and disclosure of contractual waivers, and may also specify the location and print size of provisions altering consumer rights. ${ }^{21}$ Legislation could serve the dual purpose of establishing the enforceability of certain provisions limiting a health care provider's tort liability and, at the same time, creating protections for the consumer.

True, conspicuous disclosure of certain limitations for malpractice liability on the part of the provider could prove harmful from a marketing standpoint. On the other hand, conspicuous provision for fair and impartial arbitration or "no-fault" payment for surgery-related injuries, in lieu of lengthy court proceedings, could prove very attractive. This is as it should be; if informed buyers want high standards of care and full tort process, they should get them-at the appropriate price. Those who decide, with full information and freedom of choice, to opt for a different malpractice regime also deserve to get what they want. Either way, meaningful disclosure and choice are vital.

For a health plan or provider to offer patients a contract limiting malpractice liability is mainly an economic decision. For a patient to enter into such a contract is also mainly an economic decision-at least when the patient has reasonable options. Where patients can seek the services of another health plan or provider and can obtain whatever malpractice rules and processes are desired (perhaps for higher fees) consumers are protected. Given the recent change in medical and health insurance markets to promote consumer control, as a matter of public policy a well-drawn contract limiting a health care provider's liability in certain ways should be enforceable where as a matter of fact the consumer could choose freely among reasonable options. Such contracts would advance laudable social goals, including consumer sovereignty, the promotion of choice in the provision of health care, efficiency in insurance and medical markets, and the ability to bargain freely in one's own economic and personal interest. This article next considers which specific provisions seem most reasonable and, hence, enforceable.

II

\section{Alternatives for Changing Liability Rules and Processes}

Replacing the full panoply of courtroom procedures with simpler, faster, and less expensive arbitration is a major alternative that can already be negotiated and chosen by providers and consumers in many states, as has already been noted. The other possibilities for private reform of current malpractice rules which are presented below have not yet been widely implemented, and the discussion of them is thus necessarily somewhat speculative. Judged by the standards already laid out, however, several of

20. Wheeler v. St. Joseph Hosp., 63 Cal. App. 3d 345, 358-59, 133 Cal. Rptr. 775, 784-85 (1976); W. Prosser \& W. Keeton, The LaW of Torts $\$ 68$, at 483-84 (5th ed. 1984).

21. See, e.g., Cal. Civ. Proc. Code $\$ 1295$ (West 1979) (medical care providers); Cal. Health \& SAfETy Code $\$ 1373$ (i) (West 1979) (HMO subscriber contracts). 
them appear to be legally defensible and thus worthy of a market test to see whether consumers and providers find them desirable. Many of these provisions have been proposed or enacted in statewide legal reforms of tort law. They may be more desirable as permissible private agreements so that affected parties may decide for themselves.

\section{A. Modification of the Collateral Source Rule}

In most jurisdictions, evidence may not be introduced at trial of any amounts paid or payable to the injured patient as benefits from sources not associated with the defendant. ${ }^{22}$ These "collateral sources" include private insurance or public coverage for past and future medical expenses, sick leave, and workers' compensation, as well as disability or pension compensation. ${ }^{23}$ As a result, the patient can, and often does, obtain a "double" recovery for certain economic losses. (In some jurisdictions, however, third-party payers who have made such payments may subrogate their claims against the medical tortfeasor or may by contract recover their payments from the successful malpractice claimant.) ${ }^{24}$

The collateral source rule supposes that persons should not be discouraged by malpractice damage rules from obtaining their own insurance against potential losses and also that tortfeasors should not "profit" (that is, enjoy reduced liability) after the fact by virtue of their victim's foresight and prudence in having obtained insurance. ${ }^{25}$ These premises may seem plausible in the context of most torts, which occur between strangers. The rationales are less compelling if in advance of any injury the injured party agrees with his health care provider that compensable losses under malpractice will be offset by any other medical or disability insurance benefits. Such an arrangement constitutes a mutual acknowledgment that it is not economically sensible to insure twice (or more) against the same loss and hence to pay two sets of insurance "carrying charges." One cannot argue that a subsequently injured party suffers if such an agreement has been made in advance and is thus deemed enforceable by the courts. Of course, one expects that the provider may as a result obtain lower malpractice premiums. Hence, one supposes that the patient should share in the savings in some way, perhaps through lower fees or insurance premiums or through increased services. Alternatively, the agreement could stipulate that an injured patient may recover the cost to him of obtaining other insurance; thus, the patient could incur no uncompensated loss.

22. Fleming, The Collateral Source Rule and Loss Allocation in Tort Law, 54 CALIF. L. REv. 1478, 1485 (1966); Schwartz, The Collateral Source Rule, 41 B.U.L. REv. 348, 349 (1961).

23. See generally, e.g., Annot., 77 A.L.R.3D 415 (1977); Annot., 77 A.L.R.3D 366 (1977); Annot., 11 A.L.R.3D 1115 (1967); Annot., 7 A.L.R.3D 516 (1966).

24. Helfend v. Southern Cal. Rapid Transit Dist., 2 Cal. 3d 1, 9-10, 465 P.2d 61, 69, 84 Cal. Rptr. 173, 181 (1970); Fleming, supra note 22, at 1498-1501.

25. Fein v. Permanente Medical Group, 38 Cal. 3d 137, 176-77, 695 P.2d 665, 692, 211 Cal. Rptr. 368, 395 (Bird, J., dissenting), appeal dismissed, —— U.S. ——, 106 S. Ct. 214 (1985); Fleming, supra note 22, at 1484; Schwartz, supra note 22, at 353-54. 
Some jurisdictions have already enacted legislation changing the traditional rule. In California, a medical malpractice defendant may introduce evidence of any amount payable to a plaintiff from any source, asking that any award be adjusted commensurately; the plaintiff may offer evidence of the cost of obtaining such other benefits as a compensable loss. ${ }^{26}$ This provision has been held constitutional. ${ }^{27} \mathrm{~A}$ fortiori, the less extreme proposal that health care providers may make similar agreements with their patients should be acceptable public policy. It would in no way abrogate the health care provider's liability, but only allow offset of such portion of that provider's liability as is covered by a collateral source. The patient would be fully compensated. He or she would retain the discretion of obtaining medical insurance, which may cover a portion of the negligent health care provider's liability.

It should be noted, however, that making collateral-source contracts legally enforceable will not necessarily make them practical. Health and disability insurers may well try to obtain insurance policy provisions that reduce their benefits to the extent that a third party is legally responsible for the insured's injury or illness. ${ }^{28}$ In that case, courts will have to rule on which prior contract takes precedence.

\section{B. Periodic Payments and Other Alternatives to "Lump Sum" Damage Awards}

At common law, a malpractice plaintiff, like other personal injury plaintiffs, was entitled to compensation for both past and future damages through a "lump sum" award, payable upon final entry of judgment. ${ }^{29}$ Legal scholars have long advocated periodic payments of future damages, as a benefit to plaintiffs and defendants alike..$^{30}$ Both parties benefit if the periodic payment eliminates uncertainty about the extent of future, continuing losses, including shortened life expectancy, continuing medical needs, and the like, and therefore about the funds needed to cover such losses. With periodic

26. Cal. Civ. Code $\S 3333.1$ (West Supp. 1986); see Brown v. Stewart, 129 Cal. App. 3d 331, 340-42, 181 Cal. Rptr. 112, 119-20 (1982) (medicaid lien not prohibited by Cal. Civ. Code \$3333.1).

27. Fein v. Permanente Medical Group, 38 Cal. 3d 137, 164-65, 695 P.2d 665, 684-85, 211 Cal. Rptr. 368, 387-88 (introducing evidence of malpractice plaintiff's receipt of disability benefits pursuant to CAL. Civ. CODE $\$ 3333.1$ did not unconstitutionally abrogate collateral source rule), appeal dismissed, — U.S. - 106 S. Ct. 214 (1985); Barme v. Wood, 37 Cal. 3d 174, 181-83, 689 P.2d 446, 448-49, 207 Cal. Rptr. 816, 820-21 (1984) (employer's existing statutory right to recover benefits from malpractice tortfeasor not unconstitutionally abrogated by CAL. CIV. CODE $\$ 3333.1$ ).

28. For instance, in Barme v. Wood, 37 Cal. 3d 174, 689 P.2d 446, 207 Cal. Rptr. 816 (1984), the California Supreme Court held that the legislature did not unconstitutionally abrogate an employer's statutory right to bring an action to recover a sum equal to the workers' compensation benefits paid as a result of an employee's injuries, from a third person who is liable for those injuries. However, an agreement to the same effect between an employee and a health care provider could not similarly abrogate the employer's independent statutory cause of action, although it might reduce the rights the employer may have by way of subrogation.

29. 2 F. Harper \& F. James, The Law of Torts $\$ 25.2$, at 1303 (1956).

30. Id. at 1303-04. See generally Henderson, Periodic Payments of Bodily Injury Awards, 66 A.B.A. J. 734 (1980). 
payments, defendants are protected when losses end earlier than expected, through recovery or death, and plaintiffs are protected against premature or improvident exhaustion of funds. There are many reasons that a contractual provision requiring periodic payments or other alternatives to lump sum awards should be enforceable.

Consider very large malpractice damage awards, those exceeding $\$ 500,000$. Such cases are few in number, but disproportionately large in their economic effect, both directly on the defendant(s) and on the insurer(s) involved. Liability insurance rates and availability of insurance are especially affected for those specialties most likely to be involved in claims of such magnitude such as obstetrics, neurosurgery, and anesthesiology. ${ }^{31}$ In very large damage award cases alternatives to lump sum payments would be most effective in reducing costs, while also maintaining fairness. Future damages, such as lost earning capacity and anticipated medical needs, are the major components of the largest personal injury awards. ${ }^{32}$ The multimillion dollar awards almost invariably involve a child or young adult with a life expectancy of ten years or more and continuing needs for nursing, medical, and rehabilitative care. Lump sum awards of such magnitude may exceed the insurance of even a prudent physician, and cause debilitating economic and professional stress.

The effect of lump sum damage awards on the prevailing party may be equally inappropriate. They may be too much for some, too little for others. Certain plaintiffs, or their heirs, may enjoy a windfall. For example, the award may assume large costs for future medical treatment that is never rendered due to the plaintiff's early death, unexpected improvement or nondeterioration, or as a result of medical advances. On the other hand, the plaintiff's condition may deteriorate more rapidly or he may live longer than was assumed. As a result, the damage award may run short, even with careful management, leaving the plaintiff as a public ward. Finally, improvident expenditure or investment may dissipate large awards before the injured party actually incurs the expenses that the award was designed to pay.

A contract between a health care provider or alternative delivery system and the patient or delivery system subscriber could mitigate such untoward results by requiring one of several alternatives to the traditional lump sum damage award.

One model is shown by the California Medical Malpractice Reform Act, which allows either party to insist upon periodic payments for future damages that equal or exceed $\$ 50,000$. The liable party must post sufficient security to guarantee the future payments. Payments for loss of lifetime earnings do not terminate at the plaintiff's earlier than expected death, but damages for future

31. See Posner, Trends in Medical Malpractice Insurance, Law \& ConTemp. Probs., Spring 1986, at 37, 53.

32. This and other observations in this section of the article are based on the authors' extensive personal experience and review of such publications as JURY VERDICTS WEEKLY, the ATLA LAW Reporter (American Trial Lawyers Association), and the Medical Liability Report (Litigation Research Group). 
medical care and pain and suffering may be modified by court order at that time. ${ }^{33}$

Alternatively, the parties may negotiate for an initial cash payment, followed by periodic payments (typically monthly payments). These payments are usually guaranteed by an insurance company. Occasionally, payments are made through a trust arrangement. There may be provisions for termination upon certain events or at a certain date, for life insurance or other lump sum payment at death, and a variety of other arrangements. Such a structured settlement is not an uncommon feature of after-the-fact settlements in major personal injury cases.

Vouchers for medical care and payment of lost earnings as they occur are two additional methods of reducing the guesswork about future needs. Instead of estimating future medical services for the plaintiff and the cost of treatment, the liable party may pay for insurance, establish a trust, or otherwise guarantee payment for that treatment as the need arises. In many cases, the future costs of medical care, including twenty-four-hour nursing and rehabilitation, are astronomical and are very susceptible to being too little or too great. Lost earnings are inherently more speculative still, especially if the plaintiff is young. Once lost earning capacity is established, however, fair recompense is readily made by periodic payments.

Properly structured, each of these arrangements can fully protect the plaintiff against the losses occasioned by professional malpractice, while avoiding the windfall/shortfall inequity of the traditional lump sum damage award. Hence, advance contracts calling for such postaward settlements are proper public policy. Indeed, some legislatures have already decided that periodic payments can be good public policy.

To withstand judicial scrutiny, the health care provider will probably have to establish that the planned structure of payments is not an unfair alternative to the traditional lump sum award and that patients or subscribers can freely choose or reject it. Moreover, the injured party must be adequately assured that the future payment obligations will be met. This can be accomplished by posting adequate security or by providing the backup of a major insurance program. ${ }^{34}$ From an efficiency standpoint, smaller awards may not justify the cost of administering deferred payments far into the future, but many insurers, malpractice and otherwise, should be willing to structure awards in larger cases.

A contractual provision requiring an alternative form of structuring future damage payments will not entirely avoid litigation over liability or the amount of those damages. Nor will it obviate the need for the testimony of economists, actuaries, and other such professionals. Nevertheless, the scope

33. See Cal. Civ. Proc. Code $\$ 667.7$ (West 1980); American Bank \& Trust Co. v. Community Hosp., 36 Cal. 3d 359 (1984) (holding section 667.7 constitutional). See generally Elligett, The Periodic Payment of Judgments, 46 INs. Couns. J. 130 (1979) (reviewing state laws authorizing periodic payments of awards for various torts).

34. E.g., Cal. Civ. Proc. Code $\$ 667.7$ (West 1980). 
and nature of the controversy may be greatly narrowed. For example, expected time of death need not be determined where the structured award is for the lifetime of the insured.

Controversy with regard to spending on future medical care may be practically eliminated through insurance. If a medical malpractice defendant can obtain, at a reasonable cost, insurance coverage for all the future medical needs of the plaintiff related to the injury, the plaintiff can only argue that the insurance company lacks adequate assets, ${ }^{35}$ or that another company will more adequately cover his future needs (that is, its policy contains fewer potentially applicable limitations and exclusions).

In sum, properly structured alternatives protect plaintiffs while avoiding windfalls that may not benefit the injured party, yet greatly and unnecessarily increase the costs to medical professionals.

\section{Dollar Limitations on Noneconomic Losses}

Frequently, the most unpredictable, and often the largest, component of a medical malpractice damage award is payment for noneconomic losses, such as pain and suffering, disfigurement, physical impairment, and inconvenience. Although settlements and trial awards seldom itemize separate elements of damage these awards have grown enormously in recent years. The escalating trend in noneconomic damage awards has resulted in astronomical increases in risk to health care providers and their insurers.

Among others, the California legislature has sought to combat this trend and its impact on health care costs by limiting recovery for noneconomic losses to a maximum award of $\$ 250,000$ in personal injury negligence claims against health care providers. ${ }^{36}$ Other states have also agreed that such a "cap" serves public policy. The state supreme courts of both California and Indiana have upheld the constitutionality of such limitations. ${ }^{37}$ The U.S. Supreme Court has refused to review the California decision. ${ }^{38}$ Four other states with similar limitations are Texas, New Hampshire, North Dakota, and Ohio. ${ }^{39}$

In the absence of agreement among state courts, private agreements between potential plaintiffs and defendants seem especially appropriate. Statutes have imposed rather arbitrary "caps," such as California's $\$ 250,000$ per injury limitation for all forms of noneconomic damages regardless of plaintiffs' age or condition. Private parties could be expected to bargain for

35. This is a primary objection made by personal injury plaintiffs' counsel to structured settlements.

36. Cal. Civ. Code $\S 3333.2$ (West Supp. 1986).

37. See Fein v. Permanente Medical Group, — U.S. - _ 106 S. C. 214, $215-16$ (1985)

(White, J., dissenting from dismissal of appeal); Johnson v. St. Vincent Hosp., 273 Ind. 374,404 N.E.2d 585 (1980).

38. Fein v. Permanente Medical Group,_— U.S. ——, 106 S. Ct. 214 (1985).

39. Baptist Hosp. v. Baber, 672 S.W.2d 296, 298 (Tex. Ct. App. 1984); Carson v. Maurer, 120 N.H. 925, $941-43,424$ A.2d 825, 836-38 (1980); Arneson v. Olsen, 270 N.W.2d 125, 135-36 (N.D. 1978); Simon v. St. Elizabeth Medical Center, 3 Ohio Op. 3d 164, 166, 355 N.E.2d 903, $906-07$ (C.P. Montgomery Co. 1976). 
more flexible ceilings that are better related to the type of damage, the age, and other circumstances of the injured person. There could also be provision for certain payment without regard to fault. Reasonable and flexible limitations freely bargained for by the parties should be enforceable.

\section{Plaintiff's Duty to Accept Reparative Care as a Precondition of Suit}

One problem with the medical malpractice system is that injured claimants are not economically rewarded for seeking timely reparative care. Indeed, it may be to the person's advantage to postpone care until after settlement or a jury verdict in order to emphasize the nature of the injury or to play for sympathy. A contractual reform could give the health care provider the right to offer cost-free reparative surgery or other care to an injured patient, before a suit could be brought. Such a provision could both limit the amount of damages awardable for future medical treatment and provide the patient with needed care without resort to legal process.

Some patients might not want to receive further personal service directly from an allegedly negligent provider if distrust and hostility have resulted from prior contacts, but the expectation of prompt and free aid in the event of an untoward incident could even help forestall such a deterioration in provider/patient relations. Moreover, patients could choose as their reparative physician someone other than the potential defendant. Offering the patient a reasonable choice among providers makes the arrangements conscionable and improves the chances of enforceability.

\section{E. Elimination of Punitive Damages Awards}

Punitive or exemplary damage awards are increasingly common in medical malpractice actions. The increase raises several problems. Such damages, by definition, do not necessarily relate in amount to the actual incurred injuries. Moreover, such awards are not covered by medical malpractice insurance in almost all jurisdictions. In many states, punitive damages are not limited to cases of intentional, malicious, or wanton action. They may now also be awarded for unintentional, grossly negligent, or careless conduct.

Agreements limiting the amount of such recoveries should be enforceable except where conduct is malicious. Indeed, a recent California Court of Appeal's opinion implies that an express exclusion of punitive damages from issues subject to arbitration may be enforceable. ${ }^{40}$ 


\section{III}

Conclusion:

\section{Updating Courts' Views of Medical Care and Liability Contracts}

The traditional hostility of courts to private agreements about medical liability rests on two views of the world. First, judges feel that health care consumers cannot bargain about care with providers. Although some patients cannot realistically bargain about many aspects of care at the time of service, especially nonelective care, recent experience shows that lay people can bargain equally with professional providers about many attributes of health care services. Moreover, advance contracting for health care insurance or a service plan offers a logical time and method for malpractice negotiations to occur. With good representation in negotiations by employers and unions, followed by clear information about options, and ultimate freedom of choice for each consumer, this objection has lost most if not all of its force.

Second, traditionally, courts have been concerned that any bargain will inherently disfavor the potential plaintiff. Indeed, the provisions discussed here involve limitations of traditional tort "rights." The issue, however, is how much those rights are worth to those affected-the patients who must pay higher fees and premiums for medical coverage because of a very expensive dispute resolution system and ever-higher malpractice awards, often unrelated to the actual economic needs of injured parties. There is a reasonable probability that well-conceived substitutes for traditional tort rules and processes would be well received by health care consumers-in exchange for lower health care costs and, often, speedier and fairer resolution of disputes. Supreme Court Justices look for an offsetting quid pro quo when a state changes legal rules applicable to malpractice plaintiffs in order to find the changes constitutional. ${ }^{41}$ Consumers will seek a similar quid pro quo before accepting changes-and reviewing judges should find the resulting agreements legally acceptable and binding.

41. Fein v. Permanente Medical Group, _ U.S. — 106 S. Ct. 214, 215-16 (1985) (White, J., dissenting from dismissal of appeal) (appeal should be granted because there was no quid pro quo to the injured party for the legislature's reduction of the medical tortfeasor's liability); see also Tunkl v. Regents of the Univ. of Cal., 60 Cal. 2d 92, 383 P.2d 441, 32 Cal. Rptr. 33 (1963). 